\title{
ISLAM AND BUGIS IN WEST KALIMANTAN
}

\author{
Patmawati \& Nurfaidah M. \\ Pontianak State Institute of Islamic Studies \& \\ Manado State Institute of Islamic Studies
}

\begin{abstract}
The Bugis people generally have tough character because of maritime and competitive traditions, as well as sufferings as a result of the colonialism. They also strongly uphold their honor. In West Kalimantan, the Bugis are also identical with Islam. The history of the arrival of the Bugis people in West Kalimantan can be traced, at least, to three stages which will be covered in this paper, namely in 1667 during the Treaty of Bungaya, and in late1946 through early 1947 when there was mass murder where 40,000 people were killed, and in 1950 when there was a revolt of DII/TII led by KaharMuzakkar. A year later, the migration happened because they were looking for a job as a civil servant (PNS). The role of the Bugis in the spread of Islam in West Kalimantan is known through education conducted by To-Panrita, To-Sugi, To-Warani, dan To-Sulasena.
\end{abstract}

Keywords: Islam, Bugis, West Kalimantan

\section{INTRODUCTION}

West Kalimantan is one of the provinces on the island of Borneo. The eastern part of this province is bordered by East Kalimantan, the western part by the South China Sea, the Southeastern part by Central Kalimantan, the Northern part by Sarawak (Malaysia) and the southern part by the Java Sea. West Kalimantan has an area of $146,807 \mathrm{~km} 2$ or $7.65 \%$ of the total area of Indonesia (Pontianak, STAIN research team 2010: 1). Geographically, this position puts the West Kalimantan on a strategic position, i.e. on the trade route of the South China Sea. The Malays as the indigenous people were tenacious traders, scattered through the archipelagic trade cities since Malacca was captured by the Portuguese in 1511. They often had their own settlements in the cities called Kampung Melayu. Their relations with the authorities and the society were good and they could fit in with the life of the indigenous peoples, so that their safety and work were safe from the unruly actions. In the 17th century, West Kalimantan held trade relations with Johor, Palembang, Java, South Kalimantan, Mataram, BugisMakassar and so on. Bugis-Makassar traders, in particular, did more tradein this region after they signed the Treaty of Bungaya on 18 November 1667 (Christian 
Pelras, 2006, Andi Ima Kesuma, 2004. According to Patmawati in Yusriadi et al. (2005: 114-115) the presence of the Bugis in West Kalimantan can be divided in three stages. First, during the year 1667 in South Sulawesi, especially in the Kingdom of Gowa, war occurs between Hasanuddin and the Netherlands led by Speelman. This war ended with the defeat of the Kingdom of Gowa, so the Treaty of Bungaya. Second, the late 1946 through early 1947, mass murder happened during the rampage of Captain Westerling that claimed 40,000 lives. Third, during the 1950's insurgency of DII/TII led by Kahar Muzakkar.

The three conditions mentioned above resulted in massively migration from South Sulawesi to West Kalimantan. They settled in coastal areas, such as the city of Pontianak, Pontianak district, Kubu Raya, Sambas and Ketapang district. According M.D. La Ode the number Bugis people, especially in Pontianak in 1994 was the third largest (49,666 people) after the ethnic Chinese and Malay. In Pontianak district, the Bugis people also rank third with 129,027 people after the Dayak and Malay (MD La Ode, 1997: 84). The interesting thing about this ethnic is their ability to adjust to their new surroundings. Until now there has not been a single clash with the locals or among themselves.

In the newly-settled area, this ethnic group involves themselves in politics, economy (trade), education, Islamic da'wah, plantations, fishery, agriculture and so on. In politics, the role of Opu Daeng Manambung and his brothers, still can be seen up to now, particularly with regard to the existence of the Kingdom of Mempawah. In the economic sector, Bugis migrants play an important role and they have been known as inter-island traders, and once a there was group of Bugis merchants led by $\mathrm{H}$. Amin Latif. He was also active in the Masjumi Party, once a member of the House of Representatives (DPR) of West Kalimantan Province, and one of the founders of the school Daru al-Da'wah wa al-Irshad (DDI) together with H. Abd Rahim Said (H. Beddu) in 1957 at Sungai Ambawang. In the spread of Islam, Haji Ismail Mundu as Mufti of the Kingdom of Kubu was very well known until now, and one of the staunch supporters of the construction of the mosque in the Teluk Pakedai area.

As the pioneer of plantations, in fact, it can still be seen in the third generation that is still in control of the plantations inherited from the previous generation. They are well known also as the "landlord", and live a prosperously from the results of the plantation. Another fact also shows that in West Kalimantan, the pioneer would also name the territory after their own places of origin, for example, Jl. Ujung Pandang, Jl. Selayar, Parit Wak Gattak, Wajok, Parit Wajok, Parit Bone, Jl. Ambo Tien, etc. 


\section{GENERAL DESCRIPTION OF THE BUGIS}

According to Christian Pelras, the population of the Bugis is more than four million. They inhabit the southwestern part of the island of Sulawesi. They belong to the great Austronesian family groups (Christian Pelras, 2006: 1). The ancestors of the Bugis used to roam the seas by boat to China, Malaysia, West Kalimantan, the Philippines, and Australia. In Malay literature, there are several sultans and princes Malaysia and West Kalimantan are Bugis descent, such as the Sultan of Johor, Selangor, Trenggano, abundance (Abu Hamid, 2004: 1), and Mempawah in West Kalimantan. Mattulada, in an international seminar on society, history and culture of South Sulawesi Indonesia held at the National Archives Branch of South Sulawesi, Makassar, 16th, and December 17, 1996, said that the South Sulawesi must be understood within the framework of its cultural diversity. Bugis four million people, two million people and half a million people Makassar Mandar (almost entirely Muslims). Muslim groups, because they live in the coastal region, known for their orientation to the sea. Because of its long coastlines, and its orientation to the sea, South Sulawesi is never isolated from the outside world. The sailors and traders of South Sulawesi always brought goods and ideas from other areas (Kathryn Robinson and Mukhlis Paeni, 2005: 7 \& 12).

Sulawesi sailors, according to Tome Pires, are called the Strait People, as quoted by Lapian who said that loyalty the Strait People to the sultan had started since they were in Palembang: "nos tambem somos de teu scnhorio antiguo de Palimbam sempre amdamos comtiguo" (we are also the servants of the king since we were in Palembang, we will always accompany his Majesty). Portuguese sources revealed how much contribution of the Strait People in helping the sultan at the time of establishing the kingdom of Melaka. There were 30 people accompanying him bodyguards, and when Parameswara moved from Singapore to Muar (Adrian B. Lapian, 2008: 104). Sulawesi sailors' proximity to the palace can also be seen in the Sultanates in West Kalimantan, Tanjungpura Sultanate such as: Daeng Mataku, Tuan Haji Hupas (Hapix), and Opu Daeng Manambung and his brothers, Opu Daeng Manambung as the successor of the Sultanate of Mempawah (J.U. Lontaan, 1975: 85-90). The Pontianak Sultanate was founded by Syarif Abdurrahman al-Qadri along with his wife, Utin Candramidi, daughter of Opu Daeng Manambung (Zulkifli Abdillah, 2010: 228). Until now there are a number of villages in the city of Pontianak whose names are taken from the name of region or ethnicity. During the reign of Sultan Syarif Yusuf al-Qadri namely in 1872-1895 AD, many immigrants came from outside the region of West Kalimantan. The Bugis people of South Sulawesi migrated to Pontianak and settled in villages 
near the Qadariah Palace later known as Kampung Dalam Bugis. In addition the city, they also spread to other coastal areas which are the now within the district of Pontianak (Sungai Kakap, Teluk Pakedai, Siantan, Rasau Jaya, Padang Tikar). Generally they spread in coastal areas and became farmers or owned palm plantations. At that time and until now coconut or copra is one of the commodities in the market (Zulkifli Abdillah, 2010: 235-236).

According Soedarto, "the Bugis people inhabit the suburb area of Sungai Jawi, Pal V and so on. In 1898 the Bugis became head of the village, they worked at sea and the garden." According to Christian Pelras, the Bugis characteristics are associated with tough and honor. To defend the truth, if necessary, they are willing to commit acts of violence. However, behind that tough nature, the Bugis are also known as friendly and highly appreciative of others as well as having a very high sense of solidarity (Christian Pelras, 2006: 5). Baidhillah also revealed that "among the characters of the Bugis are that they like to wander, are very tough, resolute in dealing with problem."

The Bugis tough character, according to Zainal Abidin, as quoted by Yusriadi (2008: 192-193), is influenced by three factors: first, maritime traditions; second, competitive traditions; third, long suffering as a result of colonization. One of the characteristics of the Bugis is their ability to change and adapt. This is the trait that allows them to survive everywhere for centuries (Christian Pelras, 2006: 5). According Soedarto "The Bugis are easy going, and hold the principle of "Dimana bumi dipijak, disitu langit dijunjung" which literally means "Wherever ground is stood on, the sky is hold high, meaning: wherever we live, we must observe the local custom (equivalent to when in Rome, do as the Romans do), open, flexible, sociable." The same was thing also expressed by Yusriadi who said, "the Bugis people can be regarded as an open society, ready to accept others." The ability to survive as mentioned above may also be supported by the Bugis cultural values . According H.A. Rahman Rahim, the Bugis cultural values include honesty, scholarship, decency, determination, and endeavor (HA Rahman Rahim, 1992: 144).

\section{HISTORY OF ARRIVAL}

The word 'migration' means the movement of people from one place to another. This concept might be seen from the following aspects:

a. Internal Migration, i.e. moving within a political area, usually a country.

b. External migration, moving from one country to another.

c. Immigration, moving into a region or country, and those who move are called immigrants. 
d. Emigration, moving out of a region or a state and those who move called emigrants.

e. Voluntary migration, namely moving at the will of a person without being forced by other people or circumstances.

f. Forced migration, namely the displacement of people due to politics and discrimination or natural factors such as earthquakes, volcanic eruptions and floods (Norazit Selat, 1993: 96-97).

In light of the above concept, the movement of the Bugis from South Sulawesi to West Kalimantan falls into in the concept of migration as it is still in the same region, namely the State of Indonesia, and they are referred to as migrants. Migration of the Bugis people was also done voluntarily, especially for those working in the formal sector (civil servants), such as the placement of teachers from South Sulawesi in West Kalimantan in the 1970s. Some of them had a permanent settlement in West Kalimantan. Some moved back to South Sulawesi after serving decades in West Kalimantan. Forced migration also occures to the Bugis particularly those involved in political issues (refusing to be governed by Dutch colonizers). At the end of 1670, the total destruction of Tosara and systematic destruction of suburban Wajo gave rise to the flow of refugees leaving South Sulawesi. the number of migrants from Wajo in 1670 was larger than the flow of refugees from Makassar, and it caused significant change to the population of South Sulawesi and its neighboring islands (Leonard Y. Andaya, 2004: 261), even in West Kalimantan alone there is an area called Wajo located in Pontianak district.

Leaving the State to be free of oppressive governments has been a common practice in South Sulawesi society until now. In the past, a person had several options; they could go to live in neighboring communities and put themselves under the neighboring rulers, or they could join outlawed groups or groups that acted in the system of their own behavior. There were some specific differences in the large-scale migrations in the late 17th century. They were mostly led by nobilities, which means they often had many followers. In South Sulawesi, the leaders always gathered followers of relatives, commoners, slaves, and other individuals bound by the ties of "patron client" (Leonard Y. Andaya, 2004: 261).

An example of the members of the noble family who left the area was Opu Daeng Manambung brothers. Opu Daeng Manambung whose royal title was Prince Mas Surya Negara originated from the Luwu Sultanate, son of Opu Daeng Tenri Borong ri La'ga Bin Lamadoe Salat or La Maddusila (La Patiware Daeng Parabbung a.k.a Patiarase), was the first Luwu King who converted to Islam in 1603 (Ellyas Suryani bin Soren et al., 2001: IX). The trip of Opu 
Daeng Manambung brothers showed that their wanderings were supported by three tips, i.e. the tip of the tongue (signified by the ability of diplomacy), the tip of the Badi' (well known for their courage, so they were often asked for help by Sultanates), and the tip of the 'water' through marriage.

Besides the factors described above, security which resulted in famine (rationing of rice) also triggered them to leave the area. The Central Bureau of Statistics (BPS) recorded migration between regions in 1978, 1983 and 1985 as cited Secha Alatas and Edy Priyono (1993) showed that in the area of Java and Sulawesi out-migration was higher than in-migration, while in Sumatra and Kalimantan in-migration exceeded out-migration (Kamanto Sunarto, 2004: 171). A variety of existing works showed that most of the Bugis migrated spontaneously. As proposed by Sudagun (2010: 15), the migration was normally financed by the migrants themselves or other non-government parties. This opinion is in line with the findings of the authors in the field through observations and interviews with Nahrin who reported that they moved to West Kalimantan, especially to the city of Pontianak, Pontianak regency and Kubu Raya, at their own expense, followed by the family. They came with a long boat journey which took about one and a half months to get to Pontianak. Some also traveled to Jakarta and then to Pontianak.

In the decade after World War II, according to Cristian Pelras (2006: 73), many Bugis people were constantly moving out, so the number of SouthSulawesi population was far below the average growth of the population of Indonesia, between 1969 and 1980. The number of the population of South Sulawesi even decreased by 8,762. This happened in 1930's before Luwu and Polewali were separated into West Sulawesi) and became a destination area for transmigration of the Javanese. This proved that the migration waves of the Bugis were not merely due to overpopulation or lack of land that could be cultivated in their hometown. Their migration is also an effort to find solutions to personal conflicts, to avoid humiliation, unsafe conditions, or the desire to escape from the unsatisfactory social conditions, as well as things that are not desirable due to acts of power committed by the authorities. However, the reasons mentioned seem inadequate to serve as a foundation for understanding why so many Bugis people have been migrating to establish settlements throughout the country since the late 17th century. Nor can it explain the fact that in spite of changing circumstances, their activities in the new settlements become the permanent characteristics of the Bugis until now (Christian Pelras, 2006: 370-371). 


\section{BUGIS ROLE IN ISLAMIC DAKWA}

The Bugis in South Sulawesi society in ancient times had 3 classes of society namely anakarung (nobility), to-maradeka (free man), ata (slave) (Mattulada, 26-27). Such classes are no longer found in coastal areas such as West Kalimantan. Immigrants and their descendants comprising anakarung, toMaradeka, and ata attempted to show social achievements as follows:

1. To-Panrita, namely scholars, religious leaders and wise men working for the welfare of society.

2. To-Sugi, rich people who because of their tenacity became rich business people and respected in regulating the welfare of society at large.

3. To-Warani, brave men who appeared to defend the interests of the country / Sultanate in the battle against the enemy.

4. To-Sulasena, skilled people, a kind of technocrats who seek to improve the society and state enterprises (Mattulada, 1985: 35).

To-Panrita, To-Sugi, To-Warani and To-Sulasena were all involved in proselytizing and educating the people of West Kalimantan through education when the region was still a kingdom. In the kingdom, the role of Opu Daeng Manambon as To-Warani was so important that he was crowned King in the Kingdom of Mempawah. During his reign in the kingdom of Mempawah, Islam thrived as he invited Habib Husain al-Qadri, a distinguished scholar in the Kingdom Matan (Tanjungpura) to settle in Mempawah and teach people about Islam. While Opu Daeng Manambon's role as To-Warani, Haji Ismail Mundu had a role as To-Panrita, because he was the mufti of the Kingdom of Kubu. Haji Ismail Mundu teacher was a student of the two teachers named Tuan Umar a.k.a Sumbawa and Makabro Puang Lompo. Puang Lompo was a Bugis scholar. From his teacher, Haji Ismail Mundu learnt a lot about the books that contained Islamic religious sciences. During this period, there was also a scholar named Ismail Bone, a cleric who preached in the area Sungai Kakap. Puang Lompo and Ismail Bone were less known because they were not close to the Palace. According Soedarto:

"The level of religiosity of the Bugis is remarkable, so they were well respected before the Arabs came. They were made community and religious leaders. They built settlements close to the Palace, but did not becaome bureaucrats. They had a principle that "power is temporary and someday we will fall". So, they did not joined the cronies of the kingdom because they sought to maintain self-esteem not positions. “In 1904, Haji Ismail Mundu returned to Indonesia from Mecca, and lived in the village of Teluk Pakedai that was in the territory of the Kingdom of Kubu, West Kalimantan. This was where he was called to practice and develop the knowledge that he received. As a pious man, 
he always strived to spread Islamic teachings to differentiate between truth and falsehood which was at that time began to be rampant. Haji Ismail Mundu's presence in the Teluk Pakedai could change the situation where religious life gradually improved. His success in alleviating Kubu society of ignorance won the sympathy of the King, so in 1907 Haji Ismail Mundu received the trust of the kingdom to hold the post of the mufti of Kubu kingdom. As a mufti, Haji Ismail Mundu served as a person to answer about religious issues that came from various backgrounds in the kingdom as well as from the wider community (Baidhillah, 24).

In addition to Teluk Pakedai, Haji Ismail Mundu also taught in Pontianak, at the home of Wak Kudak, in Gang Perindra, Gertak Dua. Haji Ismail Mundu did it because his students continued to grow, especially in the area of Tanjung Bunga, Kuala Karang, Sungai Bembang Timur and Kubu (Baidhillah, 45). According to Jamnah, her mother was a student of Haji Ismail Mundu. He wrote many works to be read and learnt by his students, such as Tafsir Kitab Suci al-Quran, Ushul Tahqiq, Jadwal Nikah (already certified by mufti of Johor Malaya/Malaysia) (Baidhillah Riyadhi, 2010). The book on Marriage Schedule has been studied by Didik M. Nur Haris from Universiti Malaya (Didik M. Nur Haris, 2010). According Rasmi Sattar, Haji Ismail Mundu built a madrasa in the area Teluk Pakedai. Until now in TelukPakedai, there is a tradition that when a child has not completed the recitation of the Koran, he cannot be circumcised. Every fasting month, parents and children recite the Qur'an in turn while improving the recitation.

After Indonesia's independence, and West Kalimantan became part of the Unitary Republic of Indonesia (NKRI), the Bugis people in West Kalimantan still took a role in education. One of the the most important educational and cultural movements among Muslims in West Kalimantan, led by the Bugis was a movement called Daru 'Da'wah Wal Irshad (DDI). DDI was founded by Haji Abd Rahim Said (Haji Beddu) in Sungai Ambawang in 1957. Throughout its history, the DDI movement has shown itself as a unique phenomenon in the religious life in West Kalimantan. As an organization, the DDI has proved that it is a social movement in religious education, which actively encourages the rise of the Muslim community in West Kalimantan. Basically, the DDI play two important interrelated roles: as a reformer movement and as an agent of social change. As an organization that is oriented to religious reform, the DDI aims to purify the teachings of Islam based on the principle of Sharia corresponding to ahlusunnah wal jama'ah. As an agent of social change, the DDI aims to advance knlowledge and human civilization, and convey those teachings to the people and lead them toward the implementation of these 
teachings. Maintaining unity within the Muslims, and peace in crowded public is one of the paragraphs in its statute (Statute of DDI, 1968).

In addition to the DDI madrasah and the one built by Ismail Mundu, the Bugis and people of Bugis descent also built several other madrasa and schools, among them: Madrasah Bawari in Pontianak city, madrasah in Parit Wak Gattak, Madrasah Tsanawiyah Nurul Iman in Sungai Pandan, Islamic Boarding School Assalam in Pal V (border area between Pontianak city and Kubu Raya). The main task of the teachers in madrasa and boarding schools is to be a teacher and to serve as a person that explains about of Islam. According to Soedarto, "the Bugis people contribute to the religion by becoming a preacher indirectly through the provision of examples, the caretaker of the mosque as in Mempawah and Sengkubang." The Bugis, in carrying out their duties, both as an educator and a teacher, have implemented the concept of education. According to Harun Nasution, education aims not only to fill the educated with knowledge and develop their skills, but also to develop the moral and religious aspects. This concept is in line with the concept of man that is composed of body, mind, and conscience (Saiful Mazani ed., 1998: 289-290). The Bugis people in playing a role as a da'i establish and manage educational Islamic institutions. They have shown their identity as people who willingly make sacrifices for the sake of Islamic education. The proof, in the provision of land for school building, was exemplified by Haji Ismail Mundu, Haji Abd Rahim Said (Haji Beddu), Haji Jamaluddin and many others.

\section{CONCLUSION}

The Bugis people migrated to free themselves of oppressive or tyrannical government. When migrating, they armed themselves with three tips: the tip of the tongue, indicated by the ability of diplomacy; the tip of the Badi', their well known courage, so kingdoms often asked for their help; and the tip of the water through marriage. The propagation of Islam by the Bugis people in West Kalimantan consisted of To-Panrita, To-Sugi, To-Warani, and To-Sulasena. These people have played an important role in preaching and educating the people of West Kalimantan through education since the region was still a kingdom until it joined the Unitary State of the Republic of Indonesia (NKRI). 


\section{REFERENCES}

Abu Hamid. 2004. Pasompe Pengembaraan Orang Bugis, Makassar: Pustaka Refleksi.

Adrian B. Lapian. 2008. Orang Laut Bajak Laut Raja Laut Sejarah Kawasan Laut Sulawesi Abad XIX, Jakarta: Komunitas Bambu bekerjasama dengan Ecak Frencaise d'Extreme-Orient.

Anggaran Dasar dan Anggaran Rumah Tangga DDI, 1968.

Baidhillah Riyadhi. 2010. "Guru Haji Ismail Mundu Tokoh Pendidik Kerajaan Kubu" (Makalah yang disampaikan pada Seminar Konferensi Antarbangsa Islam Borneo III di STAIN Pontianak), tanggal 4-5 Oktober. --. 2011. Guru Haji Ismail Mundu (Ulama Legendaris Dari Kerajaan Kubu), Kubu Raya: Dinas Kebudayaan Pariwisata.

Christian Pelras. 2006. The Bugis. terjemahan Abdul Rahman dkk. Dengan judul "Manusia Bugis", Jakarta: Nalar.

Didik M. Nur Haris. 2010. "Kitab Jadual Nikah Karya Guru Haji Ismail Mundu: Teks dan Analisis" (Makalah yang disampaikan pada Seminar Konferensi Antarbangsa Islam Borneo III di STAIN Pontianak), tanggal 4-5 Oktober.

Ellyas Suryani bin Soren dkk. 2001. Sejarah Mempawah Dalam Cuplikan Tulisan, Kabupaten Pontianak: Bina Ilmu Mempawah.

H.A. Rahman Rahim, 1992, Nilai-nilai Utama Kebudayaan Bugis, Ujung Pandang: Hasanuddin University Press.

Hendro Suroyo Sudagung, 2010, Mengurai Pertikaian Etnis: Migrasi Swakarsa Orang Madura ke Kalimantan Barat, Institut Studi Arus Informasi (ISAI) bekerjasama dengan Yayasan Adikarya IKAPI dan The Ford Fondation.

J.U. Lontaan, 1975, Sejarah-Hukum Adat dan Adat Istiadat Kalimantan Barat, Jakarta: Bumi Restu.

Kamanto Sunarto, 2004, Pengantar Sosiologi, Jakarta: Fakultas Ekonomi UI.

Kathryn Robinson dan Mukhlis Paeni (peny.), 2005, Tapak-tapak Waktu Kebudayaan, Sejarah dan Kehidupan Sosial di Sulawesi Selatan, Makassar: ININNAWA.

Leonard Y. Andaya, 2004, Warisan Arung Palaka Sejarah Sulawesi Selatan Abad ke 17, Makassar, ININNAWA.

Mattulada, 1985, Latoa, Yogyakarta, Gadjah Mada University Press.

M.D. La Ode, 1997, Tiga Muka Etnis Cina, Yogyakarta: Bigraf Publishing.

Norazit Selat, 1993, Konsep Asas Antropologi, Kuala Lumpur, Dewan Bahasa dan Pustaka Kementerian Pendidikan Malaysia.

Saifullah Muzani (ed.), 1998, Islam Rasional: Gagasan dan Pemikiran Prof. 
DR. Harun Nasution, Jakarta: Mizan.

Tim Peneliti STAIN Pontianak, 2010, "Sejarah Kesultanan Sambas Kalimantan Barat", Laporan Hasil Penelitian LP3M STAIN Pontianak.

Yusriadi, 2008, Memahami Kesukubangsaan di Kalimantan Barat, STAIN Pontianak Press.

dkk., 2005, Etnisitas di Kalimantan Barat, Pontianak: STAIN Pontianak Press.

Zulkifli Abdillah, 2010, Kepingan-kepingan Sejarah Umat Islam, Pontianak: STAIN Pontianak Press. 
